\title{
Eucamaragnathus desenderi, a new ground beetle species from Africa (Coleoptera, Carabidae)
} \author{
National Collections of Natural History, Tel Aviv 69978, Israel \\ † urn:lsid:zoobank.org:author:D4400870-C4A7-42B4-A4B4-B4D84DD7CDAE \\ ¥ urn:lsid:zoobank.org:author:33C90108-OD3D-4BE9-A9FA-3EE8920CA6FO \\ § urn:lsid:zoobank.org:author:4DEBE8E3-8C8C-4B50-AF55-B9527C7A50A4 \\ | urn:lsid:zoobank.org:author:B0064964-3401-4EA3-864B-6E39EBAF8EEA
}

Thorsten Assmann $n^{1, \dagger}$, Claudia Drees ${ }^{2, \ddagger}$, Andrea Matern ${ }^{1, \S}$, Andreas Schuldt ${ }^{1,1}$

I Institute of Ecology and Environmental Chemistry, Leuphana University Lüneburg, Scharnhorststr. 1, D-21332 Lüneburg, Germany 2 Tel Aviv University, George S. Wise Faculty of Life Sciences, Department of Zoology, The

Corresponding author: Thorsten Assmann (assmann@uni.leuphana.de)

Academic editor: H. Turin | Received 3 February 2010 | Accepted 10 March 2010 | Published 20 May 2011

urn:lsid:zoobank.org:pub:C561FE04-37EB-44DA-B3C2-7EEBD85DD1CD

Citation: Assmann T, Drees C, Matern A, Schuldt A (2011) Eucamaragnathus desenderi, a new ground beetle species from Africa (Coleoptera, Carabidae). In: Kotze DJ, Assmann T, Noordijk J, Turin H, Vermeulen R (Eds) Carabid Beetles as Bioindicators: Biogeographical, Ecological and Environmental Studies. ZooKeys 100: 37-46. doi: $10.3897 /$ zookeys.100.1521

\begin{abstract}
Eucamaragnathus desenderi sp. n., a new ground beetle species of the tribe Hiletini, is described from eastern and southern Africa and dedicated to the recently deceased Belgian carabidologist Konjev Desender. The new taxon is known so far from localities in Zambia (Mukuku, southeast of Mansa) and in South Africa (Bothaville, south of Klerksdorp). The new species belongs to the E. castelnaui group and is characterized by shape of pronotum, smooth or sparsely punctate pronotal transverse impression, characters of male genitalia and elytral striae continued to the apex. Illustrations of the habitus, the median lobe and its internal sac and several other morphological features are presented. An updated identification key to the African Eucamaragnathus species is given.
\end{abstract}

\section{Keywords}

Coleoptera, Carabidae, Hiletini, new species, Zambia, South Africa, identification key

Copyright Thorsten Assmann et al. This is an open access article distributed under the terms of the Creative Commons Attribution License, which permits unrestricted use, distribution, and reproduction in any medium, provided the original author and source are credited. 


\section{Introduction}

The pantropically distributed ground beetle tribe Hiletini is only poorly known, mainly because its members are rarely represented in collections. Erwin \& Stork (1985) describe in their revision 20 species arrayed in two genera. Since that time no further species have been described.

Consequently we were surprised to find a series of an Eucamaragnathus species among other ground beetles caught by the Czech coleopterologists Miroslav Snižek and Vladimír Tichý in southern and eastern Africa. The examination of the material revealed that the specimens belong to a new species. Here we describe the species and dedicate it to our deceased colleague and friend Konjev Desender due to his exceptional engagement in the fields of ground beetle ecology, evolutionary biology and taxonomy.

\section{Material}

The material examined is housed in the collections listed below:

CAM Collection of the Africa Museum, Tervuren, Belgium

CAS Working collection Th. Assmann, Bleckede, Germany (type material will be given to Zoologische Staatssammlung München)

CFA Working collection Sergio Faccini, Modena, Italy

CMA Working collection Werner Marggi, Thun, Switzerland

CSH Working collection P. Schnitter, Halle, Germany

CSS Working collection P. Schüle, Stuttgart, Germany

CST Working collection W. Starke, Warendorf, Germany (type material will be given to Westphalian Museum of Natural History, Münster, Germany)

CWR Working collection D.W. Wrase, Berlin, Germany

\section{Methods}

Measurements were made at a magnification between $12.5 \times$ and $50 x$, using an ocular micrometer in a Leica MZ 95 stereobinocular microscope. The following measurements are used in the description: Total body length is measured from the tip of the mandibles to the apex of the right elytron as the maximum linear distance; the width of the head (HW) as the maximum linear distance across the head, including the compound eyes; the length of the pronotum (PL) from the anterior to the posterior margin along the midline; the length of the elytra (EL) from the basal margin to the apex of the right elytron as the maximum linear distance; the maximum width of the pronotum $(\mathrm{PW})$ and elytra $(\mathrm{EW})$ at their broadest point; the width of the pronotal base (PBW) between the tip of the posterior angles; the width of the pronotal apex (PAW) between the tip of anterior angles. 


\section{Microsculpture was examined at a magnification of $100 \times$}

Dissections were made using standard techniques; genitalia were preserved in a mixture of polyvinylpyrrolidon, sorbitol and glycerol on acetate labels (Lompe 1989), and pinned beneath the specimens from which they had been removed. The photographs were taken with an Olympus E-330 digital camera in combination with a Leitz MZ 95. Post-processing was done in Adobe Acrobat Professional 7.0. To achieve sufficient depth of focus, up to 20 planes were captured which were copied to separate layers, and the out-of-focus planes were masked by a stacking programme (Combine Z5).

\section{Description}

Eucamaragnathus desenderi Assmann, Drees, Matern \& Schuldt, sp. n. urn:lsid:zoobank.org:act:7F180D34-C5F8-4D79-AC05-E2F727CAD2E3 http://species-id.net/wiki/Eucamaragnathus_desenderi

Type material: Holotype male: „ZAMBIA NE. 2004 / 240 km SE Mansa / 25 km SE Mukuku / 29.11. Snižek, Tichý" (CAS). Paratypes: 13 males and 8 females, same as holotype (CAS, CFA, CST, CSH, CSS, CWR). 2 males and 4 females: „RSA, NW prov. 2001 / Klerksdorp, $20 \mathrm{~km} \mathrm{~W} \mathrm{/} \mathrm{of} \mathrm{Bothaville,} \mathrm{Vaal} \mathrm{riv.} \mathrm{/} \mathrm{M.} \mathrm{Snižek} \mathrm{lgt.} \mathrm{12.1.“}$ (CAS, CWR).

Diagnosis: A macropterous species of average size for the Eucamaragnathus castelnani group, black, pronotum transverse, sides sinuate with posterior angles acute, transverse anterior impression punctulate, transverse posterior impression strongly punctate, elytral striae continued to apex. Habitus see Fig. 1.

Description: Body length $8.8-10.6 \mathrm{~mm}$; width $3.6-4.0 \mathrm{~mm}$ (holotype $10 \mathrm{~mm}$ and $3.8 \mathrm{~mm}$, respectively).

Colour: Black, without iridescence, not metallic; mandibels, mouth-parts, antennae, and tarsi partly infuscate.

Head (Figs 1 and 2) large, about one fourth less wide than pronotum (HW: 2.0 $-2.4 \mathrm{~mm}$, holotype: $2.3 \mathrm{~mm}$; ratio HW/PW: $0.75-0.78$ ). Eyes fairly large, their diameter (seen in dorsal view) about four tenth of head width; protected posteriorly by lateral extension of the cranium. Antennae robust, scape longer than the following 4 antennomeres, antennomeres $5-11$ with dense and fairly fine setae. Mesal edge of mandibles markedly serrate (mandible teeth triangular shaped). Two pairs of supraorbital furrows. Frons not punctate, except basal close to pronotal anterior margin.

Pronotum (Fig. 2) transverse (PW: 2.6 - $3.1 \mathrm{~mm}$, holotype: $3.0 \mathrm{~mm}$; PL: 1.9 2.2, holotype: $2.0 \mathrm{~mm}$ ), widest prior to middle (basally of lateral seta). Pronotum at the base broader than at the apex (PAW: $2.2-2.6 \mathrm{~mm}$, holotype: $2.5 \mathrm{~mm}$; PBW: 2.3 $-2.8 \mathrm{~mm}$, holotype: $2.7 \mathrm{~mm}$ ). Anterior margin moderately straight; anterior angles pronounced, but rounded; lateral sides clearly sinuate; posterior angles acute, basal 


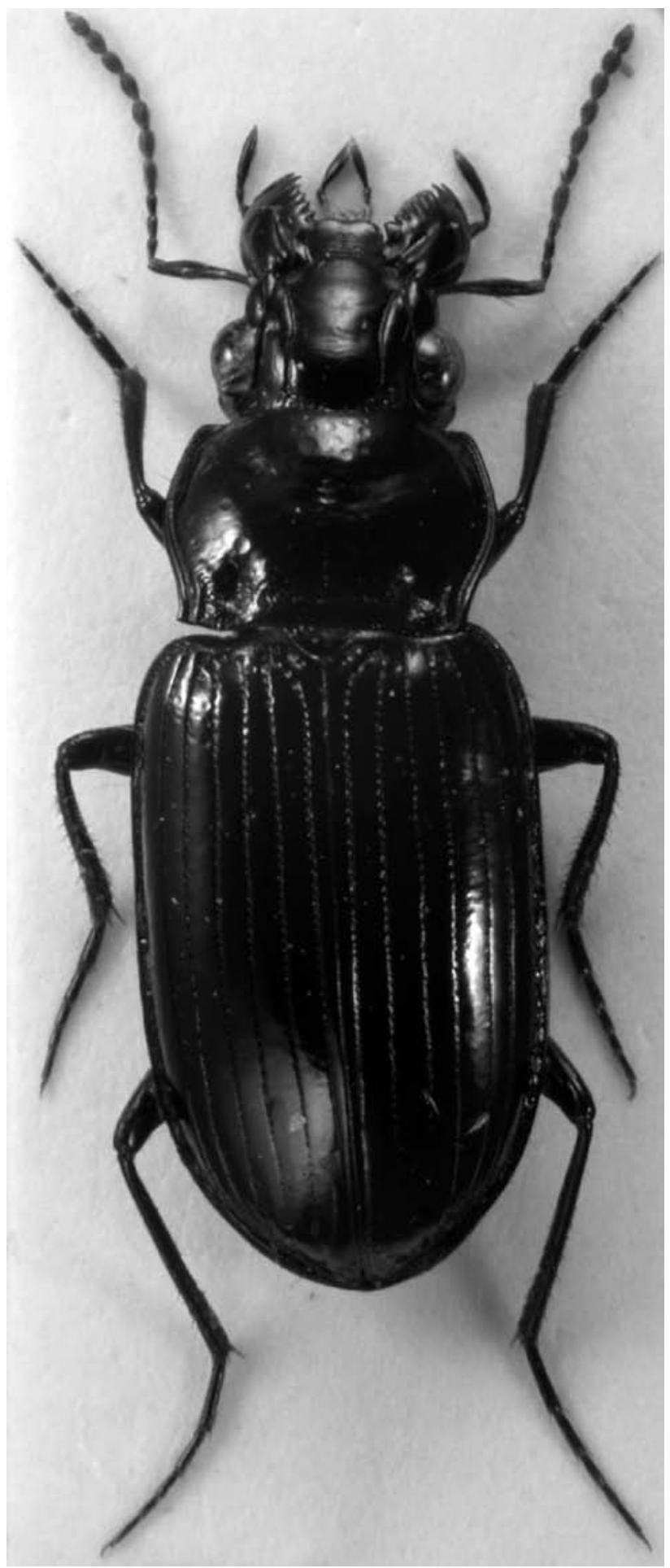

Figure I. Eucamaragnathus desenderi sp. n., habitus; holotype. 


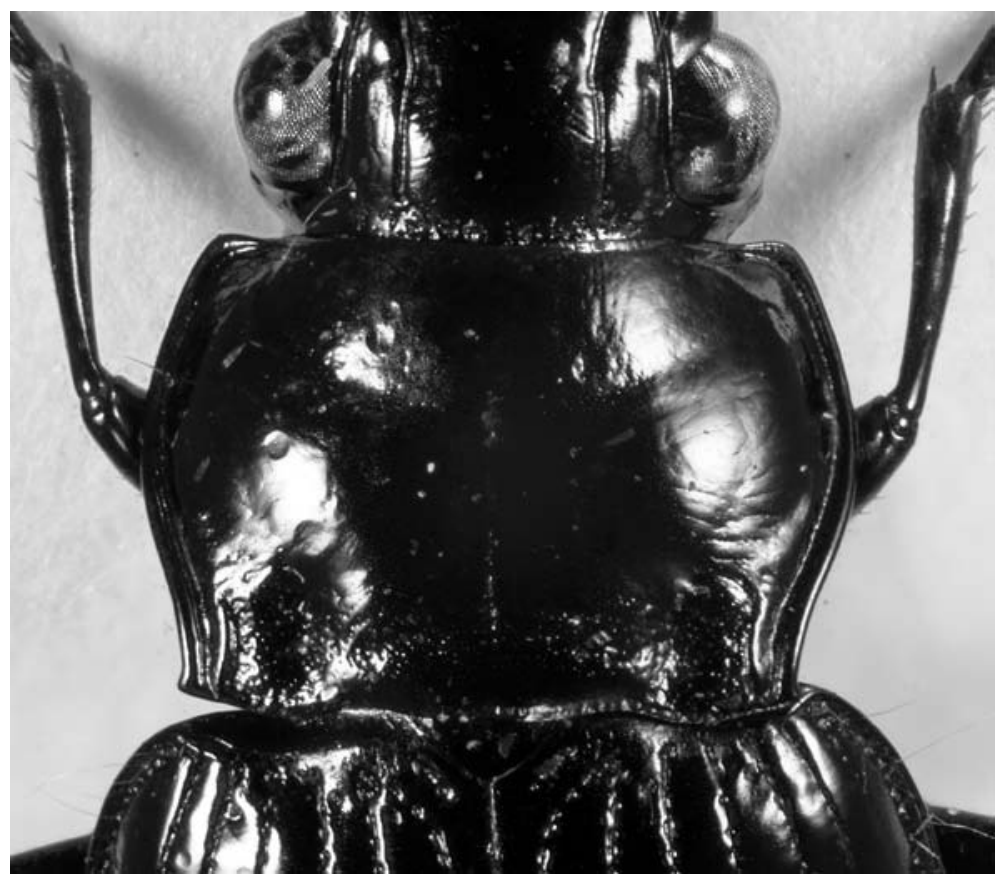

Figure 2. Eucamaragnathus desenderi sp. n., basal part of head, pronotum, basal part of elytra; holotype.

margin curved. Anterior transverse impression sparsely punctulate; lateral beads deep, not punctate; basal transverse impression deep, markedly punctate and connecting basal foveae; basal foveae deep, punctate and delimited externally by a keel-like carina without punctations.

Legs (Fig. 1) similar to those found in other Hiletini species. Males with small tooth on profemur. Single long guard seta of tarsus 5 much longer than claws. Males with spatulate adhesive setae beneath protarsi $1-3$ and mesotarsus 1 .

Elytra (Figs 1 and 3) with pronounced humeri, slightly enlarged to the end of the second third (EL: 4.8 - $5.9 \mathrm{~mm}$, holotype: $5.75 \mathrm{~mm}$; EW: 3.3 - $3.9 \mathrm{~mm}$, holotype: 3.7 $\mathrm{mm})$. Basal margin reduced, reaching $6^{\text {th }}$ interval. Scutellar striae short; elytral striae deep and punctate, at the apex less impressed, but well visible; intervals flat, at the apex slightly convex. Discal setae of third stria in punctiform depressions.

Surface with microsculpture of irregular and weak mesh patterns, meshes mainly transverse; a clear micropunctation on head, pronotum and elytra (20× magnification); surface shiny.

Male genitalia (Figs 4 and 5). Median lobe with ostium dextral. Both parameres multisetiferous, the setae of the narrow right paramere are longer than those of the broad left one.

Comparisons: Due to form of mandible teeth and long single guard seta of last tarsomere the new species belongs to the genus Eucamaragnathus Jeannel, 1937. The small tooth of profemora in males, the dextral position of the ostium of the aedea- 


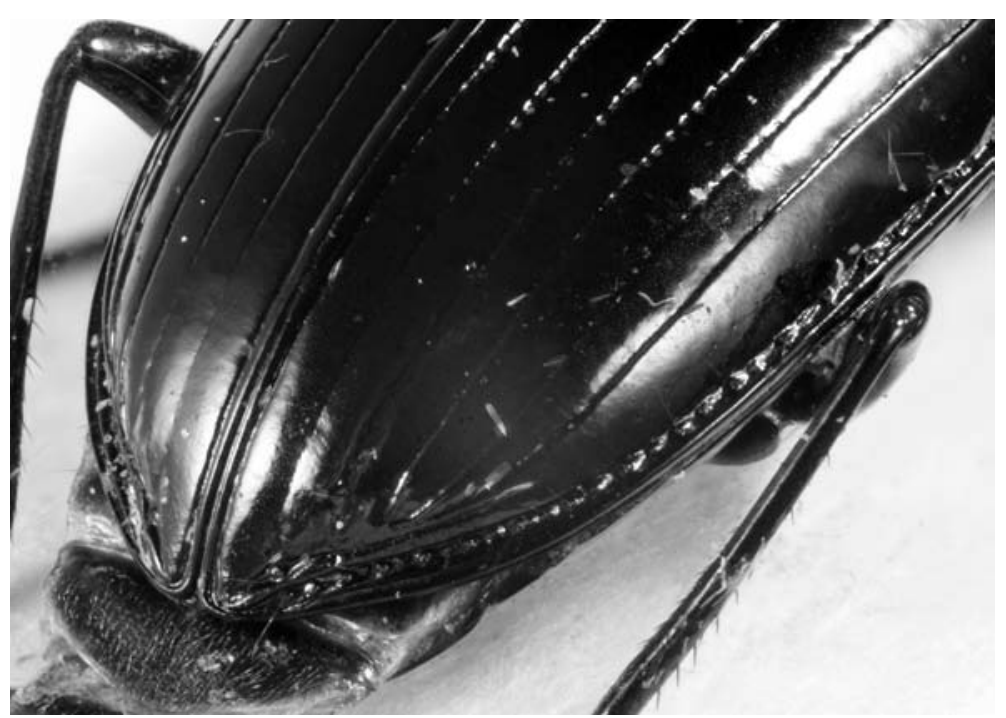

Figure 3. Eucamaragnathus desenderi sp. n., apex of elytra; paratype.

gus and elytral striae continued to the apex place the new species in the E. castelnaui (Bocandé, 1849) group (cf. Erwin and Stork 1985) which is exclusively distributed in Africa.

The new species is similar to E. castelnaui and E. fissipennis (Ancey, 1882). The best character to separate $E$. desenderi sp. n. from the nominate species of the group is the shape of the pronotum and especially the weak punctation of the pronotal anterior impression which is markedly punctate in $E$. castelnaui. In comparison to the other species of the group, $E$. desenderi sp. n. has acute pronotal anterior angles, but they are less produced than in E. oxygonus Chaudoir, 1861. Moreover the median lobe, especially its internal sac structures, of $E$. desenderi sp. n. differs from all other species of the given group. From $E$. fissipennis the new species can be easily distinguished by stronger punctation of posterior transverse impressions of pronotum (Figs 2 and 6), stronger punctation of elytral striae, which are weaker at the apex, but still well visible (Figs 3 and 7) and a microsculpture with stronger punctation.

From E. bocandei (Alluaud, 1914), which forms an own species group, the new species differs by its strong punctation of pronotal posterior impression and from $E$. suberbiei (Alluaud, 1914) it can be separated by the size of tooth on ventral surface of profemur in males.

For better distinction we present an identification key for the known members of the African Eucamaragnathus species (see below).

Etymology: It gives us great pleasure to dedicate this species to the memory of Konjev Desender, the well known Belgian carabidologist who recently deceased. We had many scientific meetings, excursions and productive collaborations with him, and we will honor his memory. An obituary is given by Lövei (2011) including a list of his publications. 


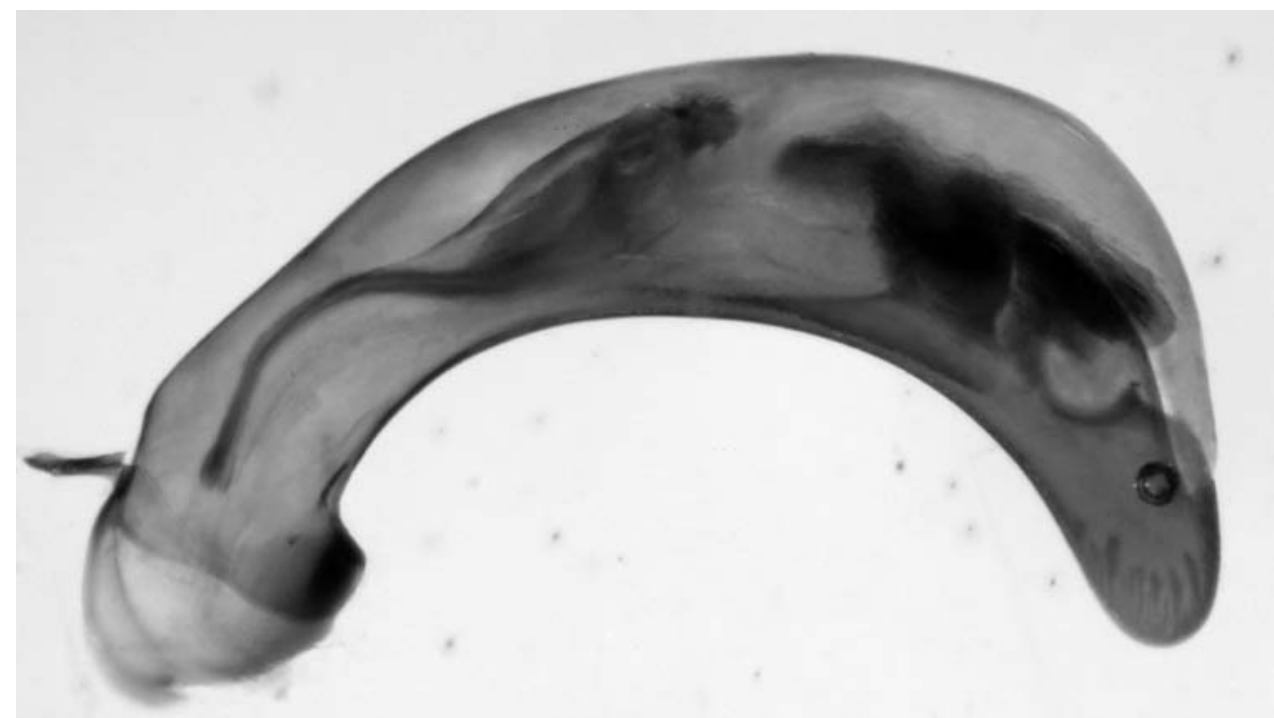

Figure 4. Eucamaragnathus desenderi sp. n., male genitalia, left lateral aspect of median lobe (aedeagus); paratype.

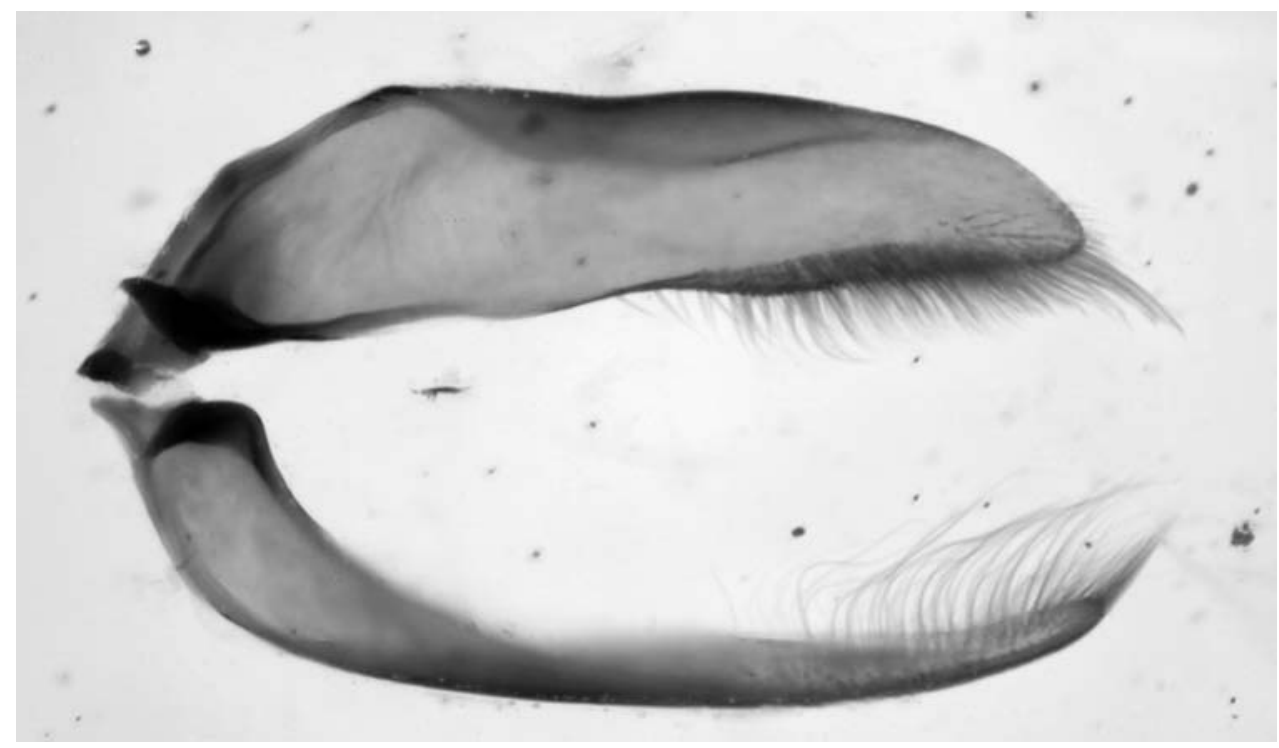

Figure 5. Eucamaragnathus desenderi sp. n., male genitalia, ventral aspect of parameres; paratype.

Distribution: Up to now E. desenderi sp. n. is only known from the two sites in Zambia and South Africa. The population from Zambia (close to the border to Congo) lies in the tropical part of Africa fitting well to the main distribution area of the tribe in tropical Africa. In contrast, Bothaville in South Africa, the other site from where E. desenderi sp. n. is known, is located between the $27^{\text {th }}$ and $28^{\text {th }}$ degrees of southern latitude, doubtless in the subtropical realm, and seems to be the most southern known 


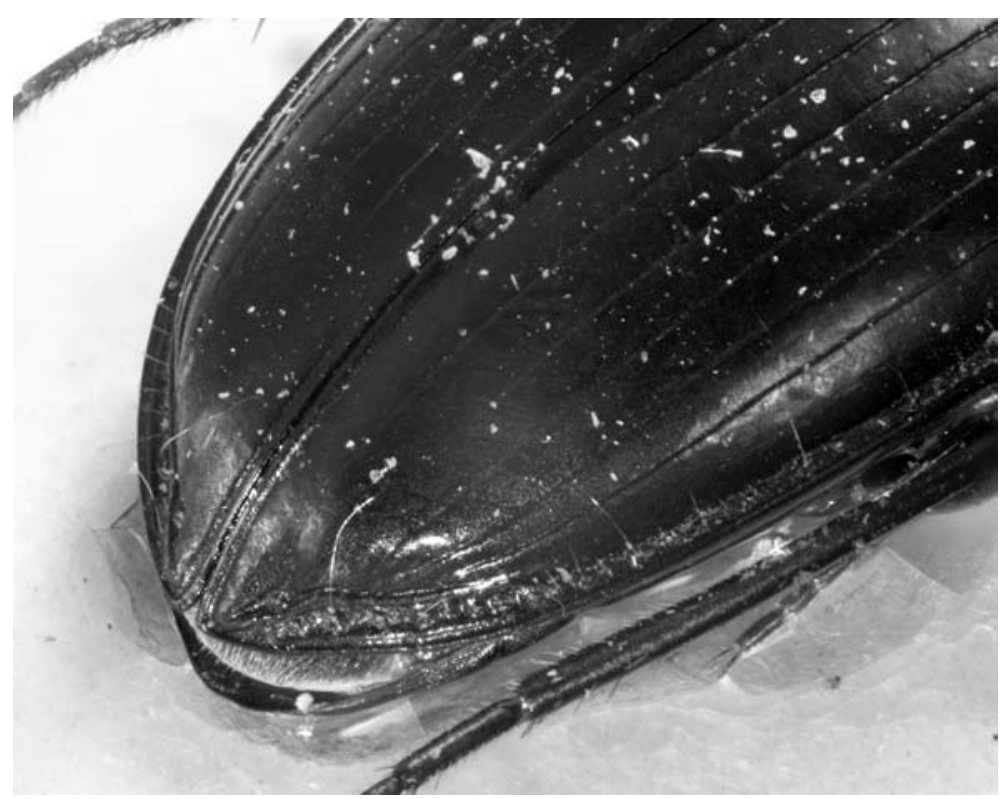

Figure 6. Eucamaragnathus fissipennis, basal part of elytra.

record of a Hiletini species in Africa (and worldwide). The wide distribution of $E$. desenderi sp. $\mathrm{n}$. in Africa is not unusual for a Hiletini species (cf. the large distribution areas of Hiletus alluaudi (Jeannel, 1937) and E. fissipennis, Erwin and Stork 1985).

Eucamaragnathus desenderi sp. n. seems to co-occur with E. fissipennis which is distributed in tropical East Africa and south-eastern Africa. E. oxygonus is known only from one locality in South Africa. All other African species of the genus Eucamaragnathus show - so far known - an allopatric distribution (E. suberbiei is an endemic of Madagascar, E. castelnaui and E. bocandei occur exclusively in tropical western Africa, Erwin and Stork 1985).

Habitat: The specimens were caught at light and habitat preferences are therefore unknown. Together with the holotype of $E$. desenderi sp. n., a single Hiletini specimen of Hiletus katanganus Basilewsky, 1948 has been found. We compared this specimen of the rarely recorded species with the type material preserved in the Africa Museum (collection of Basilewsky) and detected morphological differences. Without more material (especially males) it seems to be impossible to assign specimens conclusively to this species (see also the note in Erwin and Stork 1985: 431).

\section{Key to the African species of Eucamaragnathus Jeannel}

This new identification key is based on the one presented by Erwin \& Stork (1985), but it is modified and illustrated additionally.

1. Elytral stria 2 not continued to the apex, ending just behind last discal seta (Fig. 7) E. fissipennis (Ancey, 1882) 


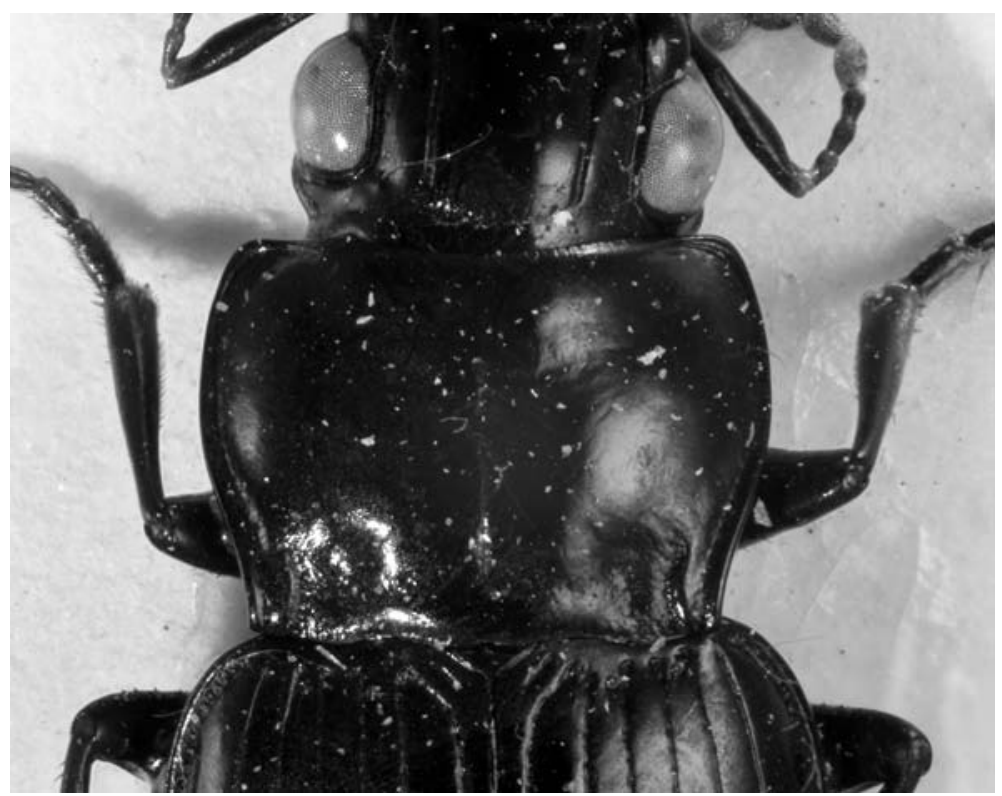

Figure 7. Eucamaragnathus fissipennis, apex of elytra.

- $\quad$ Elytral striae $1-4$ continued to apex (Fig. 3)..................................... 2

2. Pronotum with basal impression rugosely punctate. From continental Africa.. 3

- $\quad$ Pronotum with basal impression smooth, no traces of punctation. From Madagascar ................................................E. suberbiei (Alluaud, 1914)

3. Pronotum with anterior angles markedly produced, sides barely sinuate behind (Fig. 3h in Erwin \& Stork 1985) ......... E. oxygonus (Chaudoir, 1861)

- $\quad$ Pronotum sides sinuate, more or less cordiform .......................................4

4. Male with tubercle on sternum VI .................E. bocandei (Alluaud, 1914)

- Male without any specific character on sternum VI (except 1 pair of setae)...5

5. Pronotum with anterior transverse impression markedly punctate, punctation similar to that of the posterior transverse impression of pronotum.........

E. castelnaui (Bocandé, 1849)

- Pronotum with anterior transverse impression with only few punctures, punctuation less strong than on the posterior transverse impression of prono-

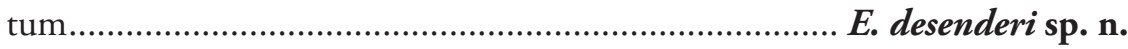

\section{Acknowledgements}

We appreciate the support of Dr Mark de Meyer (Tervuren, Belgium) and Dr Thierry Deuve (Paris, France) for the possibility to study the type material from the collections in the Africa Museum (Tervuren) and the numerous collections preserved in the National Natural History Museum, Department of Systematics (Entomology) (Paris, 
especially the general collection and Chaudoir's collection). We thank two anonymous reviewers for their helpful comments.

\section{References}

Erwin TL, Stork NE (1985) The Hiletini, an ancient and enigmatic tribe of Carabidae with a pantropical distribution (Coleoptera). Systematic Entomology 10:405-451. doi: 10.111/ j.1365-3113.1985.tb00149.x

Lompe A (1989) Ein bewährtes Einbettungsmittel für Insektenpräparate. In: Lohse GA, Lucht WH (Eds) Die Käfer Mitteleuropas, 1. Supplementband mit Katalogteil. Goecke und Evers, Krefeld, 17-18.

Lövei GL (2011) In memoriam: Konjev Desender (1956-2008) and Jean-Pierre Maelfait (1950-2009). In: Kotze DJ, Assmann T, Noordijk J, Turin H, Vermeulen R (Eds) Carabid Beetles as Bioindicators: Biogeographical, Ecological and Environmental Studies. ZooKeys 100: 1-36. doi: 10.3897/zookeys.100.1520. 